\title{
資料
}

\section{Revelstoke ダムにおける土木地質的問題}

一巨大地すべり末端部斜面の水没による安定度の低下と対策

中 村 康 夫*

\section{Engineering Geological Problems on Revelstoke Project}

- Stability Decrease of Large Slidemass due to Submergence of Toe and its Remedial Measures-

\section{1. はじめに}

Revelstoke ダムは, British Columbia Hydro and Power Authority が, カナダ国ブリティッシュコロンビ ア州北西部を流れるコロンビア川に建設した高さ $175 \mathrm{~m}$ の重力式コンクリートダムであるが，これに接続して， 右岸段丘上に高さ $126 \mathrm{~m}$ のロックフィルダムが建設さ れている。ダムサイトは, Mica ダム下流約 $130 \mathrm{~km}$, Revelstoke 市上流約 $5 \mathrm{~km}$ の Little Dalles 浃谷に位置 している $\left(\right.$ 図-1) ${ }^{1)}$ 。

コロンビア川流域に和ける Mica ダム扩よび，本ダム の適地選定調査の結果, 1956 年, 両計画ダムサイトの ほぼ中間地点の右岸に大規模な地すべりが発見された (図-1)。この地すべりは, 地名から後に Downie Slide と呼ばれるよらになったが，約 10,000 年前に発生した 表面積約 $9 \mathrm{~km}^{2}$, 体積 $1.5 \times 10^{9} \mathrm{~m}^{3}$ に達する世界最大級 の地すべりであることが確認された。Downie Slide は, 当時計画中の Revelstoke ダム上流 $65 \mathrm{~km}$ の貯水池内 （当ダムの貯水池延長は $130 \mathrm{~km}$ ) に位置し, 湛水によっ て地すべり末端部斜面が約 $60 \mathrm{~m}$ 水没するので, その安 定性が慎重に検討された。その結果, 地すべりは現在活 動中であるが，排水工によって安全率を湛水前より上げ ることが可能と判断されたため, 大規模な排水工が施工 された。さらに, 地すべりが万一急激に活動し, 貯水池 に流入して段波を発生した場合にも，ロックフィルダム が越流によって被害を受けないよう，堤高を増す等の設

* 水資源開発公団試験所

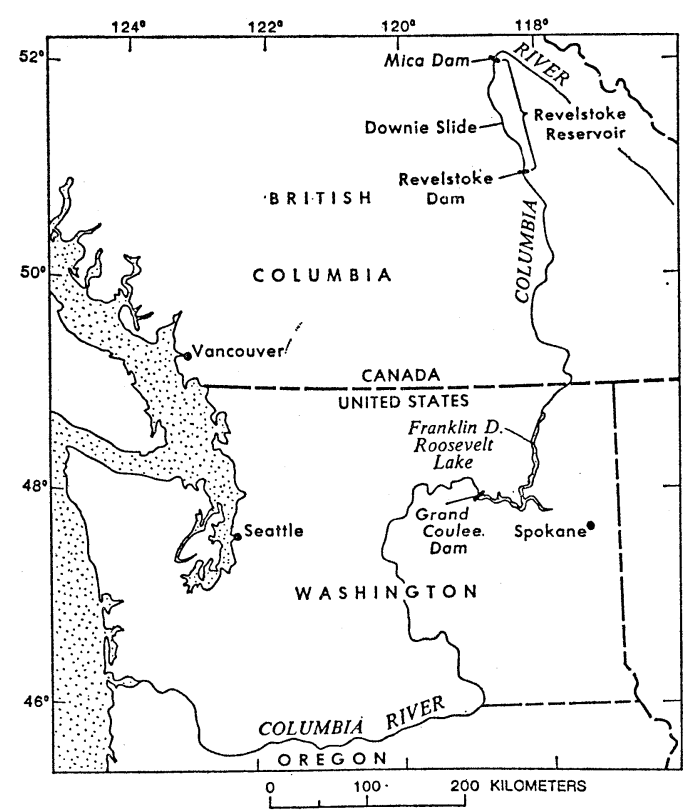

図-1 Revelstoke ダム位置図（文献 1）に加筆修正）

計変更がなされた。

ダムサイトは，片麻岩や片岩から構成されているが， 熱水変質によって特に片岩が劣化している。地質構造は 極めて複雑であるため, 着工前に正確な地質状況を把握 することは不可能であった。基礎掘削の段階で, 堤趾部 に, 熱水変質による劣化岩盤が広く分布し, 所要の剪断 強度が確保できないことが判明したので，当初予定より $153,000 \mathrm{~m}^{3}$ 多い岩盤を掘削除去するとともに，多数の 
排水工を施工した。また，劣化した片岩は，連続した弱 面を形成していたため, 掘削に伴って斜面崩壊が多発し た。さらに，ロックフィルダムが建設された右岸には厚 い氷成堆積物が分布していたが，自然状態のままでは掘 削不可能な軟弱粘土層を挟在している部分があったの で，この部分は電気浸透工法によって地盤改良した後掘 削除去した。コアは, 氷成堆積物を掘削して岩盤上に直 接盛立てたが，岩盤表面の凹凸が著しく，整形やコンク リート充填等に多大な労力を要した。

以上のように, Revelstoke ダムでは種々の土木地質 的問題が発生したが，本文は主に Downie Slide とダム 計画の関係について紹介し，斜面安定和よび，コンクリ ートダム，ロックフィルダム，放流設倩等の基礎に和け る土木地質的問題についても簡単に触れる。我が国でも 良好なダムサイトがますすす不足し，土木地質的に問題 の多い地点にダムを建設せざるを得なくなりつつある。 特に，湛水による地すべりの安定度の低下とその対策
に関しては未解明な部分が多いため，本ダムにおける Downie Slide の例は，我が国のダム建設にとって大いに 参考になると考えられる。な拉，本文はすべて容易に入 手可能な公表資料に基ついて記述しているため，判断を 下した背景や理論は必ずしも明確にされていない場合も ある。

\section{2. プロジェクトの概要}

Revelstoke プロジェクトは，図-2 に示すように，コ ロンビア川本川に建設された重力式コンクリートダム秥 よび発電所, 右岸段丘上に建設された放流設備およびロ ックフィルダム（原文はアースフィルダムと記述）等か ら構成される ${ }^{2)}$ 。れらの主要諸元は表-1 に示すと秥 りである。

\section{1 重力式コンクリートダム}

重力式コンクリートダムは, 主流路の非越流部と, 右 岸段丘上の放流設備から構成され, 非越流部には発電用

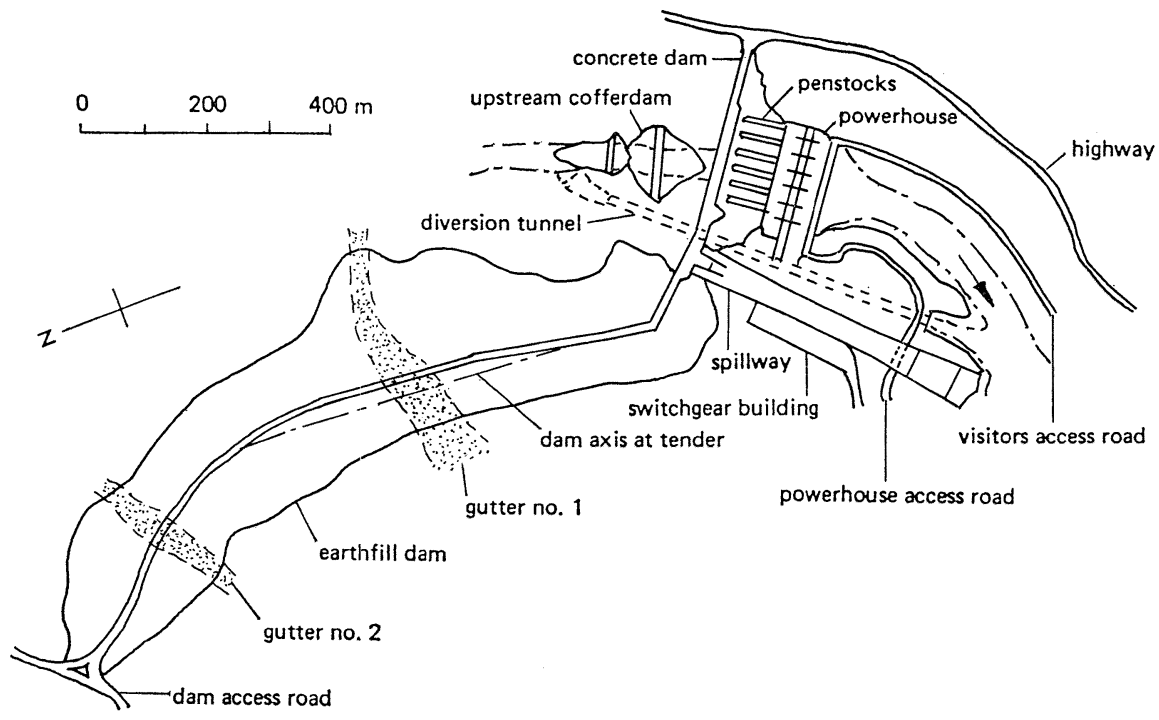

(a) 平面図

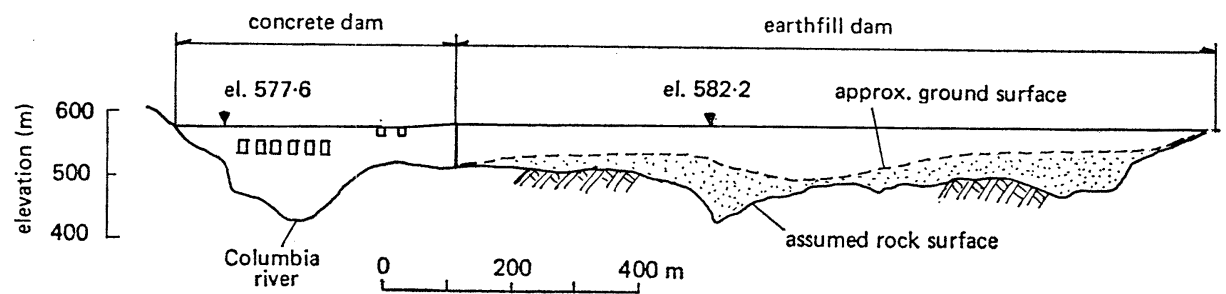

（b）ダム軸断面図

図-2，主要施設の配置（文献 2）に加筆修正） 
表-1 Revelstoke ダム主要諸元

\begin{tabular}{|c|c|c|}
\hline 水 & $\begin{array}{l}\text { 総 貯 水 容 量 } \\
\text { 貯 水 池 延 長 } \\
\text { 常 時 満 水 位 } \\
\text { 設 計 洪 水 } \text { 位 } \\
\text { 発 }\end{array}$ & $\begin{array}{r}5.18 \times 10^{9} \mathrm{~m}^{3} \\
130 \mathrm{~km} \\
\text { el. } 573 \mathrm{~m} \\
\text { el. } 574.2 \mathrm{~m} \\
2700 \mathrm{MW}\end{array}$ \\
\hline $\begin{array}{l}コ \\
\text { บ } \\
ク \\
\text { リ } \\
1 \\
1 \\
\text { ダ } \\
\text { 厶 }\end{array}$ & 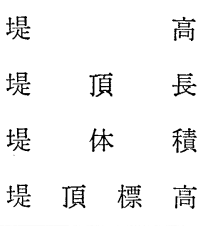 & $\begin{array}{r}175 \mathrm{~m} \\
472 \mathrm{~m} \\
2.3 \times 10^{6} \mathrm{~m}^{3} \\
\text { el. } 577.6 \mathrm{~m}\end{array}$ \\
\hline $\begin{array}{l}\text { म } \\
\text { \% } \\
\text { ク } \\
\text { フ } \\
1 \\
\text { ル } \\
\text { ダ } \\
\text { ム }\end{array}$ & 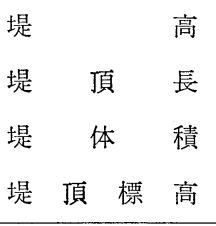 & $\begin{array}{l}\quad 1160 \mathrm{~m} \\
14.2 \times 10^{6} \mathrm{~m}^{3} \\
\text { el. } 582.2 \mathrm{~m}\end{array}$ \\
\hline 洪 & 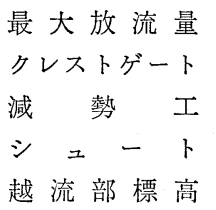 & $\begin{array}{c}7080 \mathrm{~m}^{3} / \mathrm{sec} \\
\text { 幅 } 13.7 \mathrm{~m} \times \text { 高さ } 18.3 \mathrm{~m} \times 2 \text { 門 } \\
\text { フリップバケット } \\
\text { 幅 } 38 \mathrm{~m}, \text { 延長 } 310 \mathrm{~m} \\
\text { el. } 556.2 \mathrm{~m}\end{array}$ \\
\hline
\end{tabular}

取水設備が設置されている。堤体は，幅 13 26 m の 23 ブロックから成り, 堤高 $175 \mathrm{~m}$, 堤頂長 $472 \mathrm{~m}$, 堤 体積 $2.3 \times 10^{6} \mathrm{~m}^{3}$ である。図-3 は, 最大断面をもつブ ロックの断面を示したものである。

コンクリート打設は 1980 年 7 月に開始され， 83 年 12 月に完了した。打設にあたっては，温度応力によるクラ ックの発生を防止するため，コンクリート配合，冷却方 法，打設方法等に細心の注意を払ったが，建設中より多 数のクラックが発生した。このため，種々の対策を実施 しつつ、コンクリート打設を終了した。しかし，初期湛 水 5 力月後の 84 年 3 月 12 日（貯水位標高 el. $559 \mathrm{~m}$ ) に最大断面をもつ P 3 ブロック上流面中央部に鉛直の横

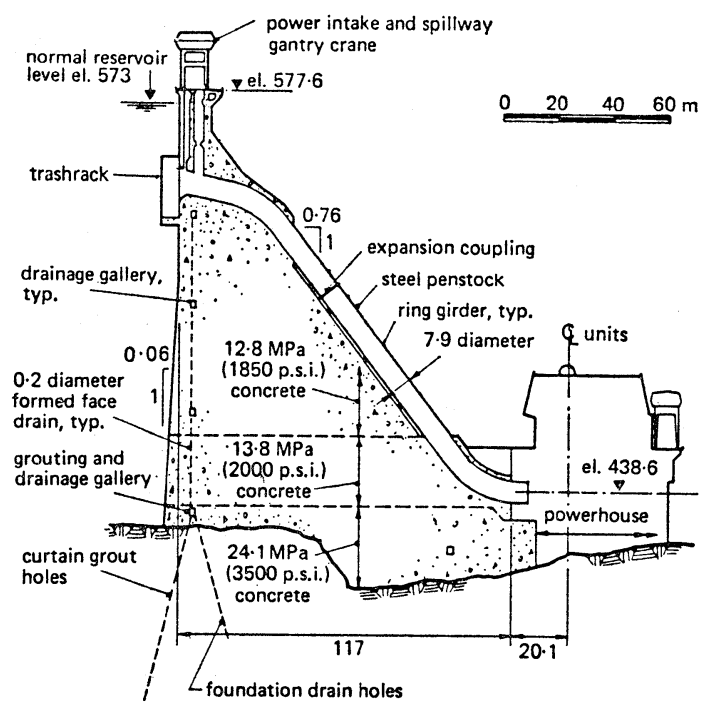

図-3 コンクリートダム断面図 ${ }^{2)}$

クラックが開口し，4標高に設けられた監査廊のうち下 位 3 標高の監査廊（図-3）に達した。漏水量は徐々に増 大し，3 日後には $174 l / \mathrm{sec}$ を示した。この時のクラッ クは, 開口幅 $6 \mathrm{~mm}$ で, 上流表面から $30 \mathrm{~m}$ 下流まで 達していた。漏水量を減少させるため, 監査廊からクラ ックに向かってボーリング孔を掘削して水圧を解放した 結果, 開口幅は $2 \mathrm{~mm}$, 漏水量は $8 l / \mathrm{sec} に$ 減少した。 コンクリートの温度規制, クラックの発生状況, 補修方 法等に関しては，文献 3）に詳述されている。

\section{2 放 流設 備}

放流設備は，右岸段丘上に建設されて和り（図-2）, シュート式洪水吐と低水放流設備から構成される（図一 4)。洪水吐は, 幅 $13.7 \mathrm{~m}$, 高さ $18.3 \mathrm{~m}$ のラジアルゲ ートを 2 門有し, 最大放流量 $7080 \mathrm{~m}^{3} / \mathrm{sec}$ である。シュ 一トは幅 $38 \mathrm{~m}$, 長さ $310 \mathrm{~m}$ で, 減勢はフリップバケッ トで行っている。

低水放流設備は, 洪水吐越流標高に達するまでの貯水

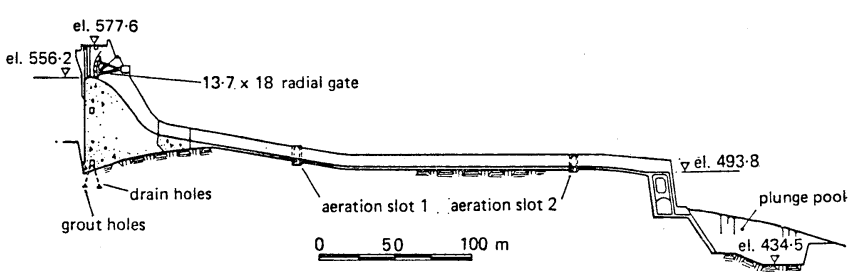

（a）洪水吐越流部

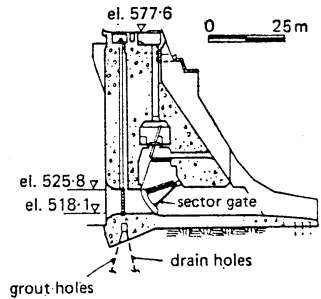

（b）低水放流設備

図-4 放流設備断面図 ${ }^{4)}$ 


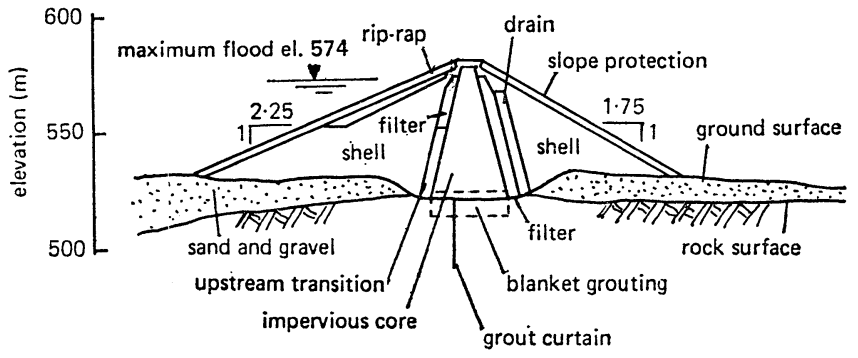

（a）砂䃯層基礎部

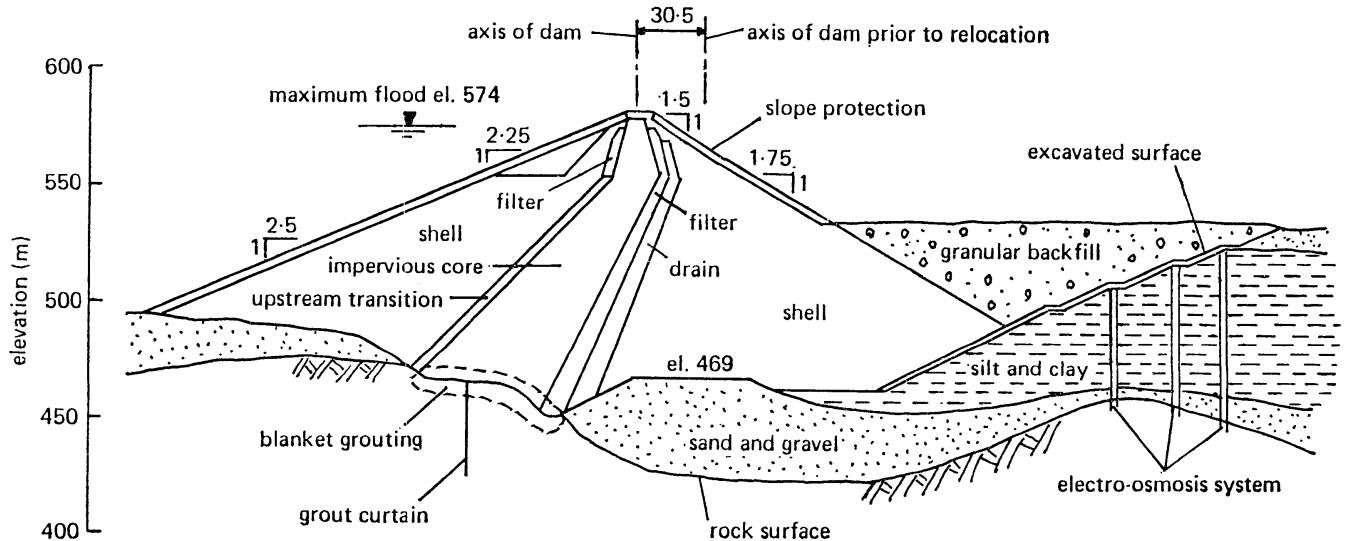

（b）シルト・粘土層基礎部

図-5 ロックフィルダム断面図（文献 4）に加筆修正）

位を調整し，Downie Slide を含む貯水池周辺地山打よ びロックフィルダム斜面の安定性に問題を生じた場合に 迅速に対処するため, 洪水吐と同一ブロックに 2 基設置 された。インバート標高は, いずれも洪水吐越流標高よ り $38 \mathrm{~m}$ 下位であり, 流量は $5.3 \times 7.6 \mathrm{~m}$ のセクターゲ ートで調整されている（図-4 (b))。

\section{3 ロックフィルダム}

ロックフィルダムは, 図-2 に示すように, コンクリ ートダムにアバットして右岸段丘上に建設されて和り, 堤高 $126 \mathrm{~m}$, 堤頂長 $1160 \mathrm{~m}$, 堤体積 $14.2 \times 10^{6} \mathrm{~m}^{3}$ の 規模を有する。盛立は, 1979 年開始され, 83 年に完成 した。

断面は，図-5 に示すと扣りであるが，同図 (b) のよ らに，自然状態のまをでは掘削困難な軟弱シルト，粘土 が分布する場所では，最も経済的にコアを岩着させるた め，傾斜コアとした。

堤体の挙動を監視するため, ピエゾメータ, 沈下計, 変位計, 歪計等, 計 281 台の計器を埋設した。これらの 計器によると, ダムは湛水後下流方向へ $5.6 \mathrm{~cm}$ 移動
し， $6.4 \mathrm{~cm}$ 沈下したが，いずれも許容範囲内であった。

\section{3.ダムサイトの地質}

\section{1 地 質 概 要}

ダムサイト付近にはほほぼ河川沿いのコロンビア川断 層を境として，西側（ダムサイト側）に古生代の Monashee 複合岩類, 東側に花崗閃緑岩類が分布しており, これらの基盤岩を厚い氷成堆積物が覆っている。コンク リートダムは，全て Monashee 複合岩類を基礎としてい るが，ロックフィルダムは氷成堆積物上に盛立てられ， コア扰よびフィルターのみ Monashee 複合岩類に岩着さ せている（図-5)。Monashee 複合岩類は，主として雲 母片麻岩から構成されて扣り，少量の大理石や珪岩を挟 在する。同斜構造を示し，走向はコロンビア川とほぼ平 行で, 左岸 (東岸) へ $30^{\circ}$ 程度傾斜している。花崗閃 緑岩は，中生代ジュラ紀〜白亜紀に貫入した巨大なバソ リスの一部であるが，ダムサイト付近では，左岸付替道 路に局部的に露出するのみである。

コロンビア川断層は, Mica ダム選定時の調査による 
と, Revelstoke ダムサイト上流約 $23 \mathrm{~km}$ の地点に位置 するとされていたが，Revelstoke ダムの地質調査によっ て初めて，ダムサイト直近に存在し，コロンビア川沿い に約 $200 \mathrm{~km}$ 連続することが明らかになった。コロンビ ア川断層は，110 160 Ma 前に形成され，45 Ma 前に再

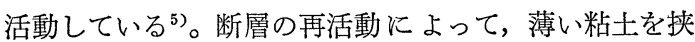
在する連続性の良い平滑なシアーゾーンが多数形成さ れ，これに沿って深部まで風化作用を受けている。ま た，断層の再活動時に岩盤は細かく破砕されたら光，熱 水変質をらけて緑泥石化して, 深部まで著しく劣化した。

コロンビア川流域のように，氷河作用を受けた地域で は, 浸食によって劣化岩盤が除去されて, 直接新鮮な岩 盤が露出しているのが一般的であり，当サイトのように 深部まで劣化岩盤が分布している例は稀である。劣化岩 艋の分布状況や性状等を, 調查段階で正確に把握するこ とが困難であったため，建設段階に入って斜面崩壊や， 基礎岩盤の強度不足等種々の大きな土木地質的問題が生 じた。

\section{2 地質調査}

1977 年の工事着手までに, ボーリング総延長 $8,500 \mathrm{~m}$, 155 孔, 横抗総延長 $300 \mathrm{~m}$ の調查が実施された。地表 地質踏查も行われたが，崖錐，崩積成堆積物，氷成堆積 物等が広く分布し，基盤岩の露頭が少なかったので，建 設前にサイトの地質状況を正確に把握することは困難で めった。このため, 建設段階に入ってから大規模な地質 調查が実施された。

建設段階では， 6 班の地質技術者が掘削面地質図の作 成, 岩盤試験, 地下水位や岩盤変位の測定等の各種調查 試験に従事した。この時期には, 新たに総延長 $7,500 \mathrm{~m}$, 170 孔に及ぶボーリングが，コンクリートダム基礎就よ び発電所基礎に称いて実施された。したがって，調查開 始以来ボーリングは, 総延長 $16,000 \mathrm{~m}, 325$ 孔に達し た。また, 直径 $0.9 \mathrm{~m}$ の大口径ボーリングが実施され， 地質技術者が中に入って，原位置に和ける地質状沉を確 認した。さらに，コンクリートダムの安全性を確保する ために着工直後, 両岸アバットメントに掘削された排水 トンネルは，調查坑として有効に利用された ${ }^{2)}$ 。

掘削面地質図は一般に，縮尺 1/120 1/240 で作成し たが，一部シアーゾーンでは $1 / 24$ で作成した。このよ らにして得られた各種地質データは，グリッド沿いの縮 尺 $1 / 240$ の 65 枚の断面図としてまとめられた

\section{4. ダムサイトにおける土木地質的問題}

\section{1 斜面安定}

ダムサイトは，片理の発達した風化片麻岩から構成さ
れ，特に右岸は流孔盤を形成しているので，斜面安定が 大きな問題となることは設計段階より認識されていた が, 地形的制約から, 右岸側で高さ $100 \mathrm{~m}$, 左岸側で高 さ $330 \mathrm{~m}$ 洼する長大法面の出現することが避けられ なかった。このため, 設計にあたっては, 斜面の安定に 特に注意を払い，ロックボルト工や排水工等の対策が計 画された。しかしながら，実際に掘削が始まると，さま ざまな規模の崩壊が多発した。代表的なものは, 右岸仮 排水トンネル（図-2）流入部付近で発生した $12,000 \mathrm{~m}^{3}$ の崩壊㧤よび，左岸アバットメントで発生した 30,000 $\mathrm{m}^{3}$ の崩壊である。また, 左岸天端付近では, シアーゾ ーンより上位の $250,000 \mathrm{~m}^{3}$ に達するブロックが徐々に 滑動したり, 発電所左岸側の岩盤は掘削が進行するに従 って緩みが著しくなった。このため，斜面安定対策は当 初設計より，はるかに大規模なるのとなった。斜面安定 対策としては, 切りな礼し, 押党盛土, ロックボルト 工，アンカー工，吹き付け，排水工等が実施された。ま た, 岩盤の挙動は, ピエゾメータ, 傾斜計, 変位計等に よって監視された。斜面安定対策に関しては, 文献 5) に詳述されている。

当初予想以上飞斜面安定が問題となった原因は, 設計 段階に㧍ける地質構造の解釈が誤っていたためである。 右岸には, 片理沿いに薄い石墨質のシアーゾーンが発達 していることが認識されていたが，厚さが数センチで， かつ褶曲したり，小断層で切られていたので，連続性は ないと考兄られていた。しかし，掘削が進行すると，シ アーゾーンは連続性が良いことが確認され，斜面安定に 極めて重大な影響を及汸すことが明らかとなった。ま た，左岸では，片理沿いのシアーゾーンに加党，緑泥石 化，深層風化，多数の節理や断層等によって劣化した岩 盤が深部まで広範团に分布していた。このような岩盤の 劣化要因は, 前述したコロンビア川断層の約 $45 \mathrm{Ma}$ 前 の再活動である5)。

\section{2 基礎岩盤の強度・透水性}

\subsection{1 コンクリートダム基礎}

斜面安定に重大な影響を及ぼした片理沿いのシアーゾ ーンは，コンクリートダムの基礎岩盤としての適否にも 大きな問題を生じた。基礎岩盤の設計に最大の影響を与 えたのは, 大規模なシアーゾーンの中に存在する最大厚 さ $5 \mathrm{~cm}$ 程度の石墨質黒色粘土層である。その面は複雑 に属曲しているら党, 小断層に切られているので調查初 期段階で，規模，性状，分布を正確に把握することは困 難であった。着工後, ダム直下流の発電所の掘削部に, この粘土を伴う大規模なシアーゾーンが露出することが 分ったので，最大断面を有する 4 つのブロックの安定性 
を確保するため, 堤趾部のシアーゾーンから上位の劣化 岩盤 $153,000 \mathrm{~m}^{3}$ を掘削除去した（図-3）。

風化岩盤や，オープンクラックが密集した岩盤は大部 分掘削除去したが，掘削が不可能な 2 力所については, コンクリートが打上がってからコンソリデーショングラ ウチングを実施した。な技，基礎岩盤の透水性は，平均 $1 \times 10^{-5} \mathrm{~cm} / \mathrm{sec}$ 程度であったため, 広範囲なグラウチン グは実施しなかった。カーテングラウチングは単列配置 で深度はへッドの $50 \%$ ，最大 $75 \mathrm{~m}$ まで実施した。

ダム堤体抢よび斜面の安全性を確保するために実施さ れた排水工は，以下のと抢りである。

1）ダム上流面近くの堤体内に標高差 $36.5 \mathrm{~m}$ で設け られた 3 つの排水坑（図-3）。

2）左岸アバットメント内に 2 玾, 右岸アバットメン 卜内に 1 坑設置された排水坑。

3）ダム上流面近くの基礎岩盤直上の堤体内に設けら れたグラウチング兼用の排水坑。堤趾部に達する支坑が 設けられている(図-3)。

4）ピエゾィータによって危険と判断された個所に， 左右岸アバットメント内の排水坑（2，3)）より実施さ れた多数の排水ボーリング。

5）堤体下の基碟岩盤中に， $3 \mathrm{~m}$ 間隔でダム高の 40 $\%$ の深さまで掘削された直径 $7.5 \mathrm{~cm}$ のドレーン。

\subsection{2 放流設備基硞}

放流設備基礎の片理沿いのシアーゾーンは，上流川側 傾斜であるので，洪水吐ブロックは湛水によって下流側 へ，自重によって川側に滑動しやすい。このため，下流 側への滑動に対する抵抗性は, ドレーン（図-4）によっ て増大させ，川側への滑動は川側ブロックが滑動に対す る抵抗力として期待できるまで打上がった後, 洪水吐ブ ロックを打設することで対処した。

当初は, シュートがより長く, 越流水を直接河川に放 流する設計であった。しかし，地質調査の結果，当核地 点の岩盤線は急崖を形成して深くなり，厚さ $60 \mathrm{~m}$ に達 する砂碩層が堆積していることが判明し，また，水理実 験の結果, 当地点で河川に直接放流すると, この砂啋層 が洗掘されて河岸および，道路に悪影響を及ぼすことが 確認されたため, シュートを短かくして，プランジプー ルで減勢することとした。

\subsection{3 ロックフィルダム基礎}

ロックフィルダムが建設された右岸段丘下の基盤岩 は，主として珠岩敊よび珪質片麻岩から構成されている が，岩盤の劣化要因となっているコロンビア川断層から やや離れているため，コンクリートダムサイトに比較し て岩質は良好である。基盤岩は厚さ $100 \mathrm{~m}$ に達する氷
成堆積物で被覆されている。承成堆積物は, 主に砂, 礫, 巨砂等から構成されているが，ダム軸のほぼ中央部 では，砂層と啋層の間に幅 $240 \mathrm{~m}$ ，深さ $60 \mathrm{~m}$ に達する 高含水比の軟かいシルトや粘土を挟在する。

基盤岩の形状呿よび氷成堆積物の厚さは，着工前には $60 \mathrm{~m}$ 間隔で実施されたボーリングによって推定されて いたが，着工後，ダム軸沿いに $15 \mathrm{~m}$ 間隔でボーリング を実施した結果，基盤岩上にダム軸を横断する幅 $60 \mathrm{~m}$ ， 深さ $45 \mathrm{~m}$ 飞達する旧河床と又られる溝が発見された。 また，これより小規模の溝が 2 力所で発見された（図一 2)。さらに，当初予定のダム軸は砂礫層が厚く，コアを 岩着させるために掘削量が多くなる場所があることが判 明したので，ダム軸を部分的に上流側へ $30.5 \mathrm{~m}$ 移動し た（図-2，5)。

氷成堆積物は, コアおよびトランジションゾーンが岩 着するまで掘削された。掘削土量は $7.7 \times 10^{6} \mathrm{~m}^{3}$ に達し たが，このうち $26 \%$ は高含水比の鋭敏なシルト〜粘土 で, 自然状態のままでは掘削が困難であり, 堤体材料と しても不適であった。この部分は，幅 $6 \mathrm{~m}$, 深さ $9 \mathrm{~m}$ 毎に電気浸透工法による地船改良（図-5(b)）を行って 掘削した後，廃棄した。残り $74 \%$ の粗粒材は，仮置き してシェル材に転用した。な特，シェルは亦成堆積物上 に盛立てた（図-5)。

当初は，基盤岩までコンクリートカットオフを設置す る設計であったが，基盤岩表面の凹凸が著しく，特に右 岸アバットメントはオーバーハングしていたので，コア トレンチを基盤岩まで掘削して，コアを直接岩盤に盛立 てるよう変更された。コアトレンチは，表面の凹凸を整 形するため，15,000 $\mathrm{m}^{3}$ の岩盤が掘削除去された。ま た，前述した旧河床と考光られる溝は，全てコンクリー トで充媜された。これは，掘削整形よりコンクリート充 填の方が低コストであることが判明したからである。整 形後の岩盤は, ウォータージェットで清掃し, コンクリ 一ト吹付やスラッシュグラウチングを実施し，コア敷に 対しては深さ $6 \mathrm{~m}$ のブランケットグラウチングを施工 した。カーテングラウチングは，コア高の $50 \%$ の深さ まで施工した。

\section{Downie Slide}

\section{1 調查経 緯}

コロンビア川流域に括沙るダム候補地点調查の結果, 1956 年, 現 Revelstoke ダムサイト上流約 $65 \mathrm{~km}$ 地点, 湛水延長 $130 \mathrm{~km}$ に及ぶ貯水池のほ涪中央部の Downie Creek の近くで，世界最大級の地すべりが発見された (図-1)。この地すべりは, 後に地名から Downie Slide 
と名付けられたが，当時計画中の Revelstoke ダムの湛 水によって, 末端部斜面が $60 \mathrm{~m}$ 水没するので，その安 定性が本プロジェクトに極めて重大な影響を与えること になった。このため, Downie Slide の規模, 性状, 活動 性等を確認することを目的として, 1965 年より地表地質 踏査, 空中写真判読, ボーリング調査, 横坑調査, 弾性 波探査, ボーリング孔を利用した傾斜, 地下水位, $\mathrm{AE}$ 等の測定, 地震動測定, 写真測量, 三角測量等の各種調 查試験が実施されてきた。

1971 年から 72 年にかけて, Downie Slide の安定性 が B. C. Hydro の技術者によって検討された結果, 湛 水による地すべり末端部斜面の水没が原因で，地すべり の大規模な活動を生じることはないと結論された。しか しながら，B. C. Hydro は，地すべりの規模が極めて 巨大であり，ダム直下流 $5 \mathrm{~km}$ に位置する Revelstoke 市への潜在的危険性を考慮して, 1973 年の着工にあたっ て, 末端部斜面の水没が地すべりの安定性に及ぼす影響 を検討するための委員会を設立した。委員会は, 下記の 事項について検討し，B.C. Hydro に対して助言するこ
とを任務とした ${ }^{1)}$ 。

1）本プロジェクト関連の種々の工事による地すべり 発生の可能性と被害状況

2）効果的な地すべり対策工

3）地すべりが再活動した際に発生する洪水の特性

初期調査の後, 委員会は 1973 75 年の調查計画を提 案した。これは，詳細な地質図を作成するとともに，延 長 $4100 \mathrm{~m}, 20$ 孔のボーリング, および延長 $226 \mathrm{~m}$ の 横坑を掘削して種々の計器を設置し，モニタリングを行 らといら内容であった。これらの調查の結果, 委員会 は, 湛水に伴ら地すべり末端部斜面の水没によって, 急 激な地すべりが発生し，貯水池へ流入する可能性がある が，排水工によって，水没による安全率の低下を補ら以 上に安定性を増すことができると結論した。この結論に 基づいて， B. C. Hydro は 1976 年, 湛水後の地すべり の安全率を湛水前より大きくすることを目的として，大 規模な排水工を実施することを決定した1)。

\section{2 規模・性状}

Downie Slide は, Revelstoke ダムサイト上流 $65 \mathrm{~km}$

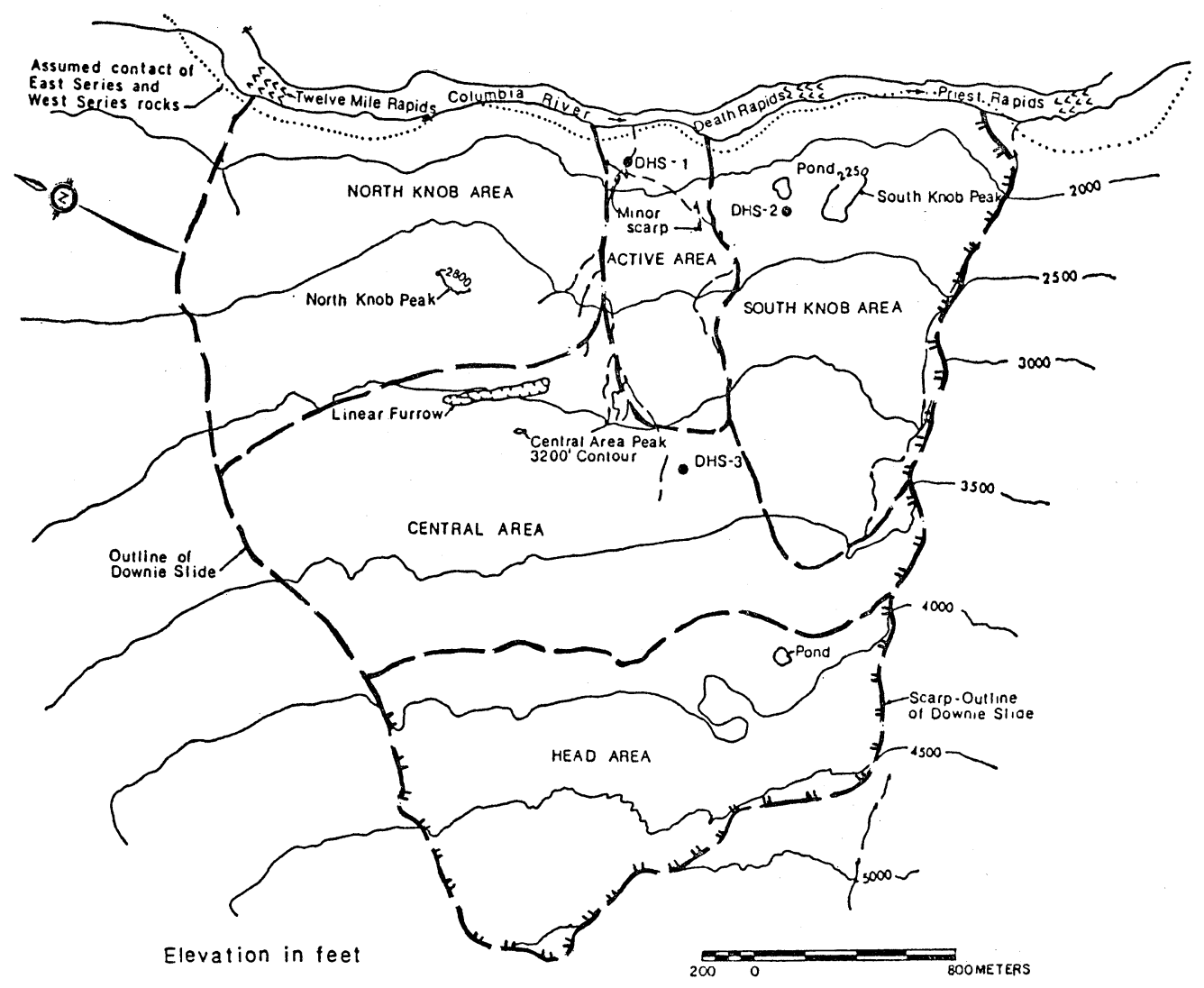

図-6 Downie Slide 平面因 ${ }^{6)}$ 
のコロンビア川右岸 (西岸) に位置し，末端部の幅 2,500 $\mathrm{m}$ ，河床標高 el. $500 \mathrm{~m}$ から el. 1,520 m の間の長さ約 3,200 m の斜面が地すべり地塊を形成している。斜面勾 配は $18^{\circ}$ でほぽ一定であり，滑落崖の比高は $140 \mathrm{~m}$ で ある。最大厚さ約 $300 \mathrm{~m}$, 面積約 $9 \mathrm{~km}^{2}$, 体積数 10 億 $\left.\mathrm{m}^{3}{ }^{6}\right)\left(1.5 \times 10^{9} \mathrm{~m}^{3}\right.$ との報告1) もある）に達する世界最 大級の規模を有する本地すべりは, 約 10,000 年前の最 終水期以降川側に，約 $240 \mathrm{~m}$ 滑動した。

地すべり地塊は，地形的な特徵から，図-6 に示すよ らに, 5 つの部分に分けられる。

1) 頂 部

三方を滑落崖に囲まれて和り，大きな岩塊が多数崖錐 中に散在している。岩塊の間には，幅 3〜10 m の凹地 が存在する。また，滑落崖の後方には，節理沿いに大規 模なテンションクラックが開口している。

2) 中央部

頂部と末端部の間の部分であり，大部分氷成堆積物に 被覆され，植生が良好である。斜面は比較的なめらかで あるが, 所々に岩塊が突出し, 地すべり活動によって変 位したと考えられる段丘が存在する。また，標高 el. 940 $\mathrm{m}$ 付近には, 氷河の差別浸食によると考兄られる大規模 な線状凹地が存在する。滑落崖は，下流側（南部）で明 瞭であるが，上流側は不明膫である。

3）末端下流部

末端部の下流側の部分で，押出し地形を呈し，平板状
の岩石で覆われた丸い小丘と数段の段丘で特徵づけられ る。ボーリングによって，末端下流部の下位に，現河床 と連続すると考学られる旧河床の砂䃯層が確認された。 表面には，多数の開口亀裂が発達している。下流側の滑 落崖は明瞭である。

\section{4）末端上流部}

末端部の上流側の部分であり，下流部之類似した押出 し地形を呈するが，小丘の高まりがより顕著である。こ の小丘は，粗粒の柘榴石や藍晶石を含む比較的堅硬な岩 石から構成されて和り，頂上部は開口幅 $7 \mathrm{~m}$ に達する テンションクラックによってブロック化している。ま たこの小丘は，礫層に被覆された幅 $160 \mathrm{~m}$ の凹地に よって，他の地すべり地塊から南西に隔てられている。 上流部の滑落崖は不明瞭である。

5）末端中央部

末端部の中央に位置し，高さ 7 10 m の崖に囲まれ た凹地を形成しているため，下流部および上流部から容 易に識別できる。泥質堆積物に被覆され，地下水面以深 には，地すべりの活動によって磨耗したと考党られる雲 母片岩の巨䃯が厚く堆積している。

末端中央部には，根曲りした樹木，変位した段丘面， 表面の小規模崩壊等現在の活発な地すべり活動の指標が 多く見られる。最も新しい地すべり活動の兆候は，標高 el. $550 \sim 610 \mathrm{~m}$ の間の各所で見られ，この標高にあっ た観測用ヘリコプター発着所 3 カ所のらち，2 カ所が崩

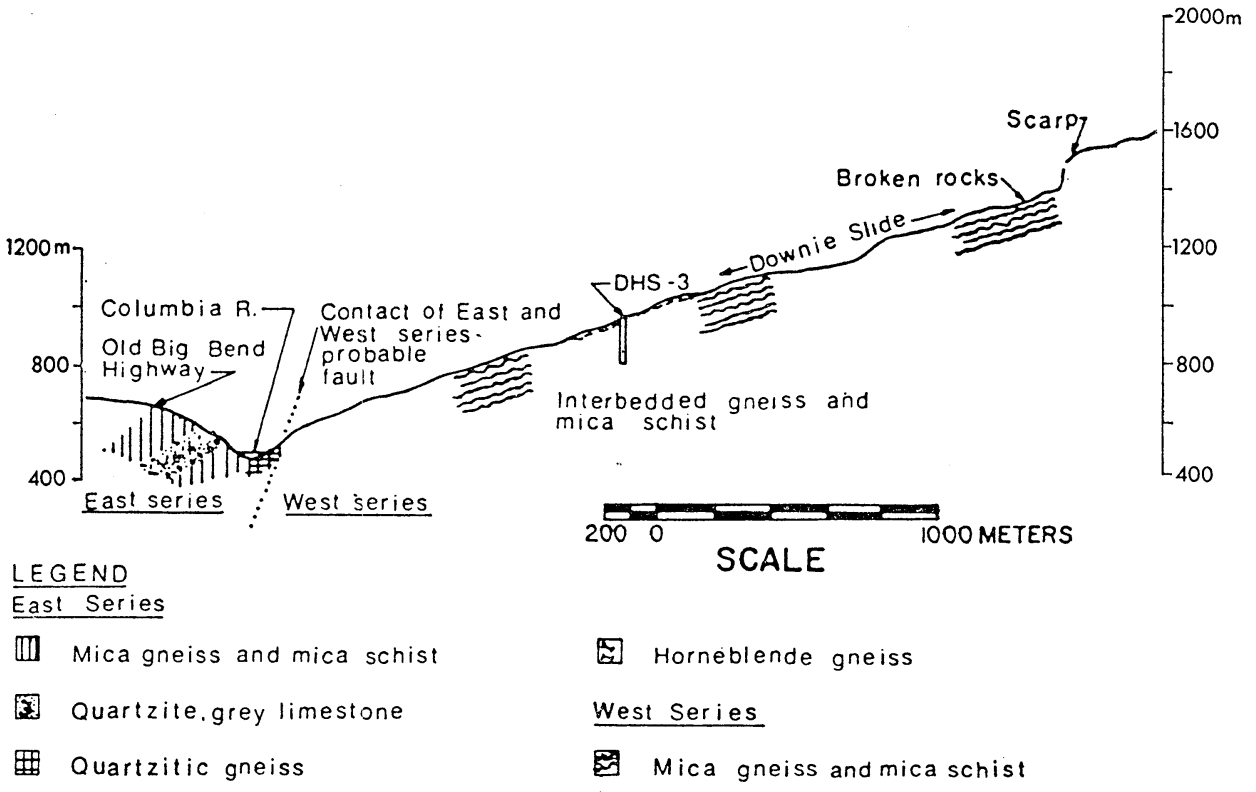

図-7 Downie Slide 地質断面図 ${ }^{6)}$ 
壞した。また，地下水位は高く，涌泉がいくつか存在す る。このように，本地域は現在の地すべり活動が目視に よって確認できる唯一の地域である。

\section{3 地質 概 要}

\subsection{1 岩 相}

本地域の地質は, 図-7 に示すように, 川沿いのコロ ンビア川断層によって右岸 (西岸) の West Series と左 岸 (東岸)のEast Series に分けられる。East Series は, 古生代の比較的堅硬な珪質片麻岩, 珪岩, 石灰岩等から 構成される。それぞれの層厚は, 数 $10 \sim 100 \mathrm{~m}$ である。

West Series は, 先カンブリア時代の雲母片岩および 花崗片麻岩を主とし, ペグマタイトや石灰岩を少量挟在 するが, Downie Slide は, ほとんど片岩と片麻岩から 構成されている。これらの岩石は, 熱水変質を受けてお り，特に片岩は著しく劣化している。ボーリングによっ て, 片岩はコア採取率が 40 50\% 程度で, 雲母が緑泥 石や絹雲母に変質して極端に強度が低下している部分を 頻繁に挟在することが確認されている。したがって，熱 水変質による片岩の強度低下が地すべり発生の大きな素 因となった。な特，片岩は，熱水変質を受けていない部 分でも著しく剝離性に富むことが特色である。片岩の厚 さは，露頭では $0.7 \mathrm{~m}$ を超えることは稀であるが，ボ ーリングでは 7 10 m に達する部分もある。

本地域周辺には，厚い氷成堆積物が分布しているが, 地すべり地内では中央部に広く分布するのみで, 他の部 分には局所的に存在するのみである。皮成堆積物は, 高 密度, 非塑性, シルト質で, 近くから供給されたと考兄

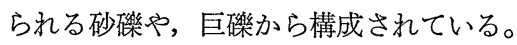

\subsection{2 地質構造}

岩盤は, 両岸とも北東に $15 \sim 30^{\circ}$ 傾斜しており, 右岸 が流机盤を形成している。右岸には，滑落崖のすぐ西を 通り，北西方向の軸を有する大きな背斜が存在して拉 り，地すべりは背斜の東翼で発生している。また，地す ベり末端部の岩盤は, コロンビア川断層の引きずりによ って部分的に急傾斜している。なお，コロンビア川断層 は急傾斜して和り，本地域には地すべりのすべり面とな る様な緩傾斜の断層は存在しない。

地すべり地外の節理系は, N 75 95 E, N 45 55 W, $\mathrm{N} 55 \sim 65 \mathrm{E}, \mathrm{N} 15 \mathrm{~W}$ の 4 方向が卓越しているが, 特 に前 2 者が顕著である。傾斜はいずれる $70^{\circ}$ 以上であ る。地すべり地内の節理系も, 基本的には地すべり地外 と同様であるが，地すべり活動の結果，約 $10^{\circ}$ 反時計回 りに回転している。

滑落崖の頂部, 南部, 北部の平均的な走向はそれぞ れ, $\mathrm{N} 50^{\circ} \mathrm{W}, \mathrm{N} 80^{\circ} \mathrm{E}, \mathrm{N} 35^{\circ} \mathrm{E}$ であり, 前者 2 は本
地域で最も顕著な節理系の走向と一致している。また， 頂部滑落崖の背後に発達するテンションクラックの走向 も，節理系の走向と一致している。しかしながら，北部 滑落崖の走向は, 上述の主要な節理系の走向と非調和的 である。

\subsection{3 水理地質}

頂部, 末端下流部, 末端上流部には全く表面水流が観 察されない。中央部では, 標高 el. 1,050 m 付近の散乱 した岩塊の間から流出し，末端中央部北側を流れてコロ ンビア川に注ぐ，末端中央部には，南側にも小さな流れ がある。これらの流れは，いずれる小規模であり，岩盤 を浸食して䫒著な水路を形成する程発達していない。

地下水位面の平均的な傾斜は, 地表面の傾斜之ほ潘等 しく約 $18^{\circ}$ であるが，末端中央部の地下水位は高く，地 表より $10 \mathrm{~m}$ 以浅であり, 涌泉も存在する。また, 末端 中央部では, 掘削終了直後孔口水頭 $3 \mathrm{~m}$ に達する被圧 水が観測されたボーリング孔もある。

\section{4 地すべり調査}

地すべりの活動性を知るために, 1965 年より三角測量

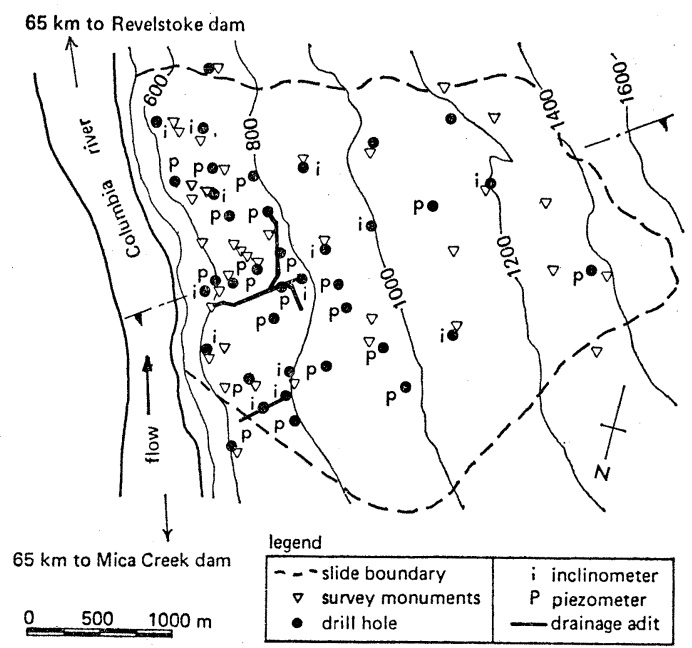

(a) 平面図

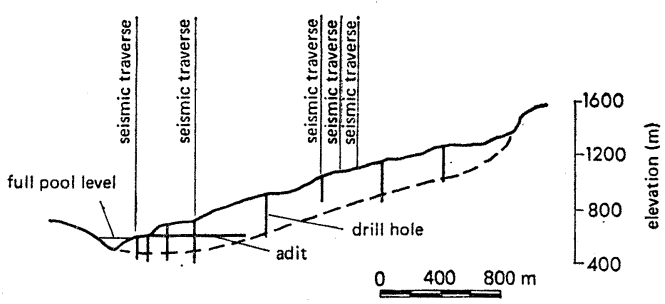

(b) 断面図

図-8 Downie Slide 調查位置図 （文献 4）飞加筆修正） 
および末端中央部に和けるボーリング孔を利用した傾斜 測定, 1968 年より距離測量が繰返し実施されてきた。末 端中央部は, 当初より活動中であることが明らかであっ たが，他の部分の活動性に関しては精度上の問題から， 1970 年代前半までは, 断定的な結論は下せなかった。ま た，当時は，すべり面も正確に把握されて挆らず，弾性 波探査や $\mathrm{AE}$ 測定等から，深さ $125 \mathrm{~m}$ 程度と推定され ていだ)。このような状況から，1973 年着工にあたって 設けられた委員会は, 地すべりの規模, 性状, 活動性等 を明らかにすることを目的として，5.1 に示す調查計画 を提案した。最終的には，図-8 亿示すような大規模な 調查が実施された。すなわち，表面変位を測定するため 45 本の測量杭が設置され，すべり面扗よび地質状況を 確認するため 38 孔のボーリング（最深 $365 \mathrm{~m}$ ) が掘削 された。ボーリング孔には，地下水位測定のため 100 以 上のピエゾメータ，打よび深部の活動状況を調査するた め傾斜計が設置された。さらに, 地表地質踏査, 空中写 真判読, 横坑調査, 地震観測, 写真測量等が実施され た。

以上の各種調查の結果, Downie Slide は現在活動中で あり, 移動速度は $10 \mathrm{~mm} / \mathrm{year}$ 程度であることが判明 した。また，すべり面深度は, 最大 $300 \mathrm{~m}$ 程度で, 体 積も数 10 億 $\mathrm{m}^{3}{ }^{6)}\left(1.5 \times 10^{9} \mathrm{~m}^{3} \text { 程度との報告もある }\right)^{1)}$ に達することが明らかとなった。

\section{5 地すべりの成因}

コロンビア川流域の上うに, 水河期に氷河が発達した 地域では，地すべりは稀な現象ではない。乞れは，氷河 期に形成されたU字谷の急斜面が，氷河の融解とともに 不安定化するためである。本地域は, 氷河期には最高標 高 $\mathrm{el} .940 \mathrm{~m}$ 程度まで氷河に覆われていた。また，右岸 は流れ盤を形成しているら光，斜面内には熱水変質によ って強度が極端に低下した緩傾斜の片理をもつ片岩層が 連続的に分布している。さらに, 地質調査の結果, 本地 域には，地すべり面となるような緩傾斜の断層は存在せ ず，地下水位もかなり高いことが確認された。このた め, 氷河が融解すると間もなく, 緩傾斜の片岩の弱層に 沿って地すべりが発生したものと推定される。発生当初 の地すべりは川方向にではなく，川側上流（北東方向） に滑動したと考兄られる。これは, 一般的に地層が北東 川側に $30^{\circ}$ 程度傾斜しているのに加え, 南部では顕著な 滑落崖が発達するのに比較して北東部では滑落崖が不明 瞭であり, 堆積地形を示すことからも推定される（図一 6)。地すべりの発生時期は, テフラによって約 10,000 年前と推定されているが，いずれの時代にも急激な滑動 は生じていない。

\section{6 地すべり対策工およびダム設計面での対応}

\subsection{1 地すべり対策工}

Revelstoke ダムの湛水によって, Downie Slide 末端 部の斜面は約 $60 \mathrm{~m}$ 水没する。調查の結果, 地すべりは 現在活動中であり, 末端部斜面の水没によって急速な地 すべりが発生する可能性が指摘されたため, B. C. Hydro は 1976 年, 湛水後の地すべりの安全率を湛水前の自然 状態に抢けるよりる大きくすることを目的として, 最も 効果的で現実的な対策工として排水工を実施することと した。図-8 に示すように，末端中央部拉よび末端上流 部の満水位直上標高に排水トンネルが 2 坑掘削された。 排水トンネルの総延長は $2.4 \mathrm{~km}$ に達するが，末端中央 部のものは大規模で， 2 本の支坑を有している。排水卜 ンネルからは, 総延長 $13.5 \mathrm{~km}$ に達する排水ボーリン グが実施された。これらの地すべり対策には， 2 期 5 年 を要した。

排水工を実施した結果, 地下水位は $120 \mathrm{~m}$ 低下し,

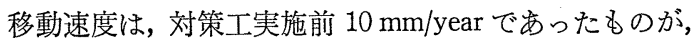
$2 \mathrm{~mm} /$ year に低下した。また, 湛水後も傾斜計やピエゾ メータ等による観測を継続しているが, 全データは地す ベりが湛水前より安定化したことを示している。

\subsection{2 ダム設計面での対応}

Downie Slide は，排水工によって湛水後も十分安全性 を確保できることが確認されたが，さらに慎重を期すた め, 急速な滑動を生じて貯水池へ流入した場合に発生す る段波について検討された。すなわち，ダム上流 $65 \mathrm{~km}$ の地点で発生した地すべりによる段波の最大波高, 伝達 状況, 減衰状況等について検討するため, 水理模型実験 やシミュレーションが実施された。これらの検討の結 果, ロックフィルダムの越流や重大な被害を防止するた めに，以下の設計変更がなされた。

1）コンクリートダムよりもともと $3 \mathrm{~m}$ 高く設計さ れていたロックフィルダムの高さを，頂部の傾斜を部分 的に急にすることによって，さらに $1.5 \mathrm{~m}$ 高くした。

2) 水理模型実験によって，ロックフィルダムの右岸 アバットメント部は，他に比較して段波の波高が高くな ることが示されたため, ロックフィルダム取り付け部は, 傾斜を急にすることによってさらに $1.2 \mathrm{~m}$ 高くした。

3） コンクリートダムとロックフィルダムの接合部下 流斜面を，コンクリートで固結した重いリップラップ材 で保護した。

\section{6. おわりに}

Revelstoke プロジェクトは，コンクリートダムの基礎 岩盤㐨よび斜面, ロックフィルダムの基礎岩盤就よび氷 
成堆積物, ダムサイト上流約 $65 \mathrm{~km}$ の貯水池内に存在 する巨大地すべり等, 土木地質的に多くの極めて困難な 問題をかかえていたが，1985 年ほぼ予定通りの工期と工 費で完成した。これは経験豊富な設計・施工技術者の導 入, 現場監督員と設計技術者の良好な意志疎通, 必要時 に护各種専門家の迅速な導入, 設計と施工の定期的 な見なおし，得られた地質状況の設計への迅速なフィー ドバック等によるものである。

本文をまとめるにあたり，(財)国土開発技術研究セン タ一調査部菅原捷次長（前水資源開発公団試験所第三試 験課長）には原稿を読んでいただき，有益な御助言をい ただいた。また, 資料の収集に際しては, 建設省土木研 究所地質研究室脇坂安彦研究員に協力していただいた。 ここに厚く謝意を表する。

\section{引用文 献}

1) Schuster, R. L. (1979): Reservoir-induced land- slides, Bull. Int. Assoc. Eng. Geol. No. 20, pp. 8-15.

2) Forster, J. W. (1986): Geological problems overcome at Revelstoke, Water Power and Dam Construction, Vol. 38 , No. 7, pp. 53-58.

3) Brunner, W. J. and Wu, K. H. (1985): Cracking of the Revelstoke concrete gravity dam mass concrete, Proc. 15th Int. Cong. Large Dams, Q 57, R 1, pp. 1-21.

4) Forster, J. W. (1986): Geological problems overcome at Revelstoke, Part Two, Water Power and Dam Construction, Vol. 38, No. 8, pp. 42-45.

5) Moore, D. P. and Imrie, A. S. (1982): Rock slope stabilization at Revelstoke damsite, Proc. 14th Int. Cong. Large Dams, Q 53, R 21, pp. 365-386.

6) Piteau, D. R., Mylrea, F. H. and Blown, I. G. (1978): Downie Slide, Columbia River, British Columbia, Canada, in: Rockslides and avalanches, 1, Voigt, B. ed, Elsevier Scientific Publishing Company, New York, pp. 365-392.

（昭和 62 年 4 月 15 日受付, 昭和 62 年 6 月 9 日受理） 